\title{
Needs Analysis of the English Writing Skill as the Base to Design the Learning Materials
}

\author{
Andi Tenri Ampa ${ }^{1 . *}$, and Hidayah Quraisy ${ }^{2}$ \\ ${ }^{1}$ English Department of Faculty, Teachers Training and Education Unismuh, J1. St.Alauddin 259, \\ Makassar 92114, Indonesia \\ ${ }^{2}$ Social Sciences Department, Faculty of Teachers Training and Education Unismuh, Jl. St.Alauddin \\ 259, Makassar 92114, Indonesia,
}

\begin{abstract}
This research used a descriptive method. It was aimed at identifying students' learning needs for the English writing skill as the base for designing the learning materials. Writing skill covered the analysis of the types of paragraph, types of text, the components of writing and paragraph development. The subjects of the research were the fourth semester students that consisted of 330 students. The samples were taken $15 \%$ randomly, so the number of samples was 50 students. The research used a questionnaire as the instrument to get responses from the students about their learning needs. The results showed that the learning needs for the writing skills coped with the types of paragraph development, the types of text, and components of writing skill. The types of paragraph development included the ways by definition $(79.7 \%)$, classification $(67.0 \%)$, listing $(59.3 \%)$, cause effect (47.7\%), example $(47.3 \%)$, and comparison $(45.7 \%)$. The types of text consisted of description $(66.0 \%)$, news items $(59.7 \%)$, narration $(58.7 \%)$, discussion $(56.7 \%)$, recount $(57.0 \%)$, and exposition $(50.7 \%)$. The components of writing skill contained structure $(79.6 \%)$, vocabulary $(79.4 \%)$, content $(62.0 \%)$, organisation $(53.6 \%)$ and mechanic $(34.0 \%)$. The implication of the findings would be the base of teaching and learning process, especially in designing the learning materials for the English writing skill.
\end{abstract}

Key words: Needs Analysis, Writing Skill, Learning Material

\section{Introduction}

There are two categories of language skills, namely receptive skills and productive skills. Receptive skills are the skills to understand the message being heard and read, while the productive skills are those that produce messages or ideas through spoken and written text.[1] The processes of productive skills are the processes of producing the language codes that begin with the idealization stage of the speaker's thinking. Furthermore, the election stage of language forms as ideas that appear at the stage of idealization, then at this stage the verbal linguistic codes produce the speech.

In other words, the productive skill process begins with a semantic encoding, which is the stage for the preparation of ideas, then the grammatical decode of conceptualization in grammatical units and semantic decode, namely the understanding of the concepts of ideas. Both skills are basic in obtaining language especially in English. This research focuses on

\footnotetext{
*Corresponding author: atenri59@yahoo.com
} 
the writing skill as one of the productive skills. The results of the researcher's observations indicated that from the four English skills (listening, speaking, writing \& reading), speaking and writing skills as the produuctive skills are most difficult to be perceived by the students. They have difficulties expressing ideas. The research results show that fifth semester students still low ability in writing English essays, especially in content, grammar and the use of transitional signals in writing. Similarly, in English speaking skills, the results of the observations showed that the students are still lacking in English. They generally have difficulty on the use of vocabulary and grammar [2]. Therefore, as a lecturer needs to provide solutions to improve English writing skills.

In writing skills, there are ten types of paragraph development: by listing, by examples, by comparison, by contrast, by definition, by classification, by space and time, by process, by cause and effect, and by generalisation [3]. These types of paragraph are different in content, but the components of each paragraph that should be paid attention in writing paractice are similar; those refer to structure, vocabulary, content, organisation and mechanic. Besides, there are several kinds of text, such as: narrative, recount, procedure, report, exposition, descriptive, discussion and news items [4]. These types of text are important to discuss in teaching and learning the English writing skills. However, the types of paragraph development, text and the components of writing should be met by the students' needs.

To design the learning materials, it is necessary to match with the students' needs. Therefore, prior analysis of learning needs for the English writing skills is required. Needs analysis for the English speaking skills had been investigated and the results indicated that the learning needs for speaking skills are English pronunciation (88\%), vocabulay (92\%), and structure $(90 \%)$. Furthermore, they also need to learn the function of speaking skills, those are interaction (43\%), transaction (92\%) and performance (92\%)[5]. By identifying the students' learning needs, the materials of learning will match the students' needs, so they can be motivated to learn well.

This research is intended to describe the students' needs to learn the English writing skills as the base to design the learning materials. It concerns with the types of paragraph development, the types of text to be learned, and the components of writing that are needed to be discussed in the teaching and learning process. To achieve the effectiveness of teaching, it is required to match the needs and the ability of the students. The previous research of needs analysis for a developmental reading, writing, and grammar course had been conducted, and the results focused on the appropriate approach for the development of the course [6]. In addition, another previous research of needs analysis to find out the learning style, skills priorities, current deficiency, and alternative methodologies chinese college students. Therefore, this research focused on the material needed by students as the novelty of the other reseachers [7].

\section{Literature Review}

\subsection{Learning Needs}

Learning needs deals with the needs of the individuals since they have learned. This need will be motivated for individuals to learn continuously. The basic human needs are from the lowest level to the highest level. This called the human needs level'. In other words, every situation that is less than it should be indicates a "need". If the gap is large or causes consequences, it is necessary to place as a priority that must be overcome [8].

\footnotetext{
*Corresponding author: atenri59@yahoo.com
} 
The learning needs vary that means everyone tends to have different learning needs [9]. So, the learning needs wanted by someone in the country may be different from the learning needs of people living in urban areas. The perceived need for learning last year may also be different from the perceived the learning needs in the future. If a learning need has been met, and then the other learning needs that must be met through the learning activities must be met. Therefore, the learning needs should be identified through an individual approach.

Needs are the permanent tendencies that exist within a person's motivation to achieve a certain goal. The need for learning is essential to identify as the foundation for the preparation of the learning program. The learning needs that have been identified will provide direction where the program activities are addressed. It is necessary because the need in learning is the basis that describes the distance between the learning objectives desired by the learners or the actual learning conditions. Each learner has different needs that should be identified to determine what needs the learner will have in potential and eventually become his needs.

In addition, the learning need is a current learner's competence compared with the competence of learners who should be mastered. The gap includes knowledge, skill and attitude. In the implementation of the learning needs, involvement of learners is needed because the potentials that exist in each learner will be indicated according to their individual learning needs. The learning needs will be arranged carefully and sequentially, then determined by the priority of learning needs or basic interests to be fulfilled through the learning activities.

\subsection{Needs Analysis}

Needs Analysis is a procedure for collecting information about learners' needs. Its purpose is to establish key learning outcomes and requirements in the design and delivery of a course or learning activity [10]. The needs relate to the characteristics, concerns and potential constraints of the students. The analysis seeks to match possible techniques and materials to these needs and thus identify whether the design is appropriate to the intended goals [11]. In the other words, needs analysis involves doing some kinds of activity with a learner in order to find out what their learning needs are, because a good understanding of learners' needs can contribute to successful course planning. Furthermore, need analysis means a plan for gathering information to make decisions about priorities [12]. In curriculum development, need analysis is the process by which one defines educational needs and decides what their priorities are [13]. Furthemore, needs analysis is defined as a process of needs while determining priorities. Needs analysis is a method to know the difference between the desired conditions with the existing conditions. The desired conditions are often referred to as ideal conditions, while existing conditions is often called real conditions [14]. So, needs are basically the gap between what is already available and what is expected.

There are several things that attach to the notion of need analysis. First, need assessment is a process that means there is a series of activities in the implementation of need assessment. Need assessment is not a result, but a certain activity in the effort to make certain decisions. Second, the need itself is essentially a gap between hope and reality [14]. Thus, the need assessment is an activity to gather information about the gaps that each student should have with what they already have.

\footnotetext{
*Corresponding author: atenri59@yahoo.com
} 


\section{Method}

The research was a descriptive method that aimed to describe the learning needs for the English writing skills. The populations of the research were the fourth semester students that consisted of 330 students. The samples were taken $15 \%$ randomly, so the number of samples was 50 students. The researcher used a simple random sampling. The instrument used was a questionnaire that aimed to get the responses from the students about the learning needs. Data analysis used were: first, identifying and scoring the students' responses; second, doing percentage of students' responses; third, ranking the percentage of students' responses; fourth, deciding the level of students' needs.

\section{Results and Discussion}

The results of the research cover the students' need analysis in learning the English writing skills. Writing skills refer to the types of paragraph development, the types of text, the components of writing that are needed to be learned by the students.

There are six types of paragraph proposed to be selected by the students. The description of students' responses are shown in the following table:

Table 1. Types of Paragraph Development

\begin{tabular}{|c|l|c|c|}
\hline No & Types of Paragraph Development & F & \% \\
\hline 1 & Development by Definition & 239 & 79.7 \\
\hline 2 & Development by Classification & 201 & 67.0 \\
\hline 3 & Development by Listing & 178 & 59.3 \\
\hline 4 & Development by Cause Effect & 143 & 47.7 \\
\hline 5 & Development by Example & 142 & 47.3 \\
\hline 6 & Development by Comparison & 137 & 45.7 \\
\hline
\end{tabular}

The students' responses indicate that the ranks of paragraph development types needed to be learned by the students are (1) development by definition, (2) development by classification, (3) ) development by listing, (4) ) development by cause effect, (5) development by example, and (6) development by comparison. The highest level needed by the students is the paragraph development by definition. From 300 responses, there are 239 responses $(79.7 \%)$ that have determined the development by definition as the first choice followed by the other types of the paragraph development. It indicates that all types of paragraph development are needed by the students in learning the English writing skills. Recall the previous statements [3] that there are ten types of paragraph development. However, only six types are firstly needed by the students. The four types of paragraph development: by contrast, by space and time, by process, and by generalisation are not responded by the students at that moment.

Furthermore, there are six types of text which are needed by the students in learning the writing skills. The frequency of students' responses are shown in the following table:

Table 2. Types of Text

\begin{tabular}{|c|l|c|c|}
\hline No & Types of Text & F & \% \\
\hline 1 & Description & 198 & 66.0 \\
\hline 2 & News items & 179 & 59.7 \\
\hline 3 & Narration & 176 & 58.7 \\
\hline 4 & Recount & 171 & 57.0 \\
\hline
\end{tabular}

\footnotetext{
*Corresponding author: atenri59@yahoo.com
} 


\begin{tabular}{|l|l|c|c|}
\hline 5 & Discussion & 170 & 56.7 \\
\hline 6 & Exposition & 152 & 50.7 \\
\hline
\end{tabular}

The students' responses in Table 2 indicate that the rank of needs on the types of text is from description to news items, narration, recount, discussion, and exposition. However, the greatest percentage of the type is a descriptive text $(66 \%)$, while the fewest level of need is an exposition (50.7\%). The other types of text are not responded by the students.

In writing skills, the components needed to be learned by the students are structure, vocabulary, content, organisation and mechanic. The percentages of the students' responses are shown in the following table:

Table 3. Components of Writing

\begin{tabular}{|c|l|c|c|}
\hline No & Components of Writing & F & \% \\
\hline 1 & Structure & 199 & 79.6 \\
\hline 2 & Vocabulary & 176 & 79.4 \\
\hline 3 & Content & 155 & 62.0 \\
\hline 4 & Organisation & 134 & 53.6 \\
\hline 5 & Mechanic & 85 & 34.0 \\
\hline
\end{tabular}

Data in Table 3 indicate that the English structure (79.6\%) and vocabulary (79.4\%) in writing take the first and the second ranks to be discussed in learning the English writing skills, being supported by the other components: content, organisation, and mechanic. Vocabulary is a list of words, and the word is a core of language. However, the words should be put in correct positions or a string of words should refer to the structure of language. Each class of words has its own use and function in any string. Every language has its own system as a rule that should be obeyed in that language.

\section{Conclusion}

The English writing skill as a productive skill is normally put as the last sequence among the four language skills. It seems right that writing is the last skill which is acquired by children in getting their first language. For the purpose of achieving the writing skill, a number of components are essential to have for the students; they are structure, vocabulary, content, organisation, and mechanic. Structure and vocabulary are the first two needs to be possessed by the students in learning the English writing skill. In making the English paragraph, a variety of ways for the paragraph development are certainly needed by the students. In fact, there are six important types of paragraph development that the students really need in their writing task. Then, the types of text also frequently make the students confused, so that they also need them. Therefore, the matters being discussed in this research should be taught to the students for the sake of their writing development in the future.

\section{Acknowledgements}

The research received a grant from Directoriate General of Higher Education, Ministry of Research and Technology, Indonesia. Thus, it is a must for us to express indebtedness and our thanks.

\section{References}

\footnotetext{
*Corresponding author: atenri59@yahoo.com
} 
1. G. B. Mundhe. Teaching Receptive And Productive Language Skills With the Help of Techniques. IJE. 1, 2:1-6. (2015)

2. A.T. Ampa. The students'Ability to write the English Productive Skills. Makassar: Unismuh (2015)

3. M. Imhoof and H. Hudson. From Paaragraph to Essay: Developing Composition Writing. England: Longman Group Ltd. (1975)

4. M. Anderson \& K. Anderson. Text Types in English. Australia: Macmillan Education. (1997)

5. Ampa, et al. The Students' Needs in Developing Learning Materials for Speaking Skills in Indonesi. JEP. 4 (17):171-178. (2013)

6. R. C. Cunningham. Needs Analysis For a Developmental Reading, Writing, and Grammar Course at a Private Language School in Cambodia University of Hawai ' $i$ at Mānoa. (2014). w.hawaii.edu/sls/wp-content/uploads/2014/08/Cunningham.pdf

7. C. Jie. English Learner Needs Analysis: A Case Study of Beijing Institute of Petrochemical Technology (BIPT). IJHSS. 3, 1, (2013).

8. A.H. Maslow. Toward a psychology of being. Start Publishing LLC. (2013).

9. R. Frost. A training course and manual on the learning process. https://www.quora.com/ What-does-learning-needs-mean-What-are-they-How-arethese-needs-best-me. (2014)

10. J.D. Brown. Foreign and second language needs analysis. In Long, M.H.\&Doughty,C(Eds.), The handbook of language teaching(pp. 269-293). U.K.: Wiley-Blackwell. (2009)

11. M. Shang, M.Dr. Needs Analysis. http://slideplayer.com/slide/5352155/. (2008).

12. Seels and Glasgow. Making Instructional Design Decisions. Second Edition. http://ocw.metu.edu.tr/pluginfile.php/3298/course/section/1175/20121127191305441. Pdf. (1990)

13. C. McNeil. Training Needs Analysis. https://4good.org/cheryl-meneil/training-needsanalysis-table. (1985).

14. G. Anderson. A Proactive Model for Training Needs Analysis. JEIT. 18, 3, 23-28. (1994).

\footnotetext{
*Corresponding author: atenri59@yahoo.com
} 